\title{
Esikuivatun nurmisäilörehun säilöntäainekäsittelyn vaikutukset kasvavien lihanautojen ruokinnassa
}

\author{
Arto Huuskonen ${ }^{1)}$, Arja Seppälä2,3) ja Marketta Rinne²) \\ ${ }^{1)}$ Luonnonvarakeskus (Luke), Tuotantojärjestelmät, Halolantie 31A, 71750 Maaninka, \\ arto.huuskonen@luke.fi \\ ${ }^{2)}$ Luonnonvarakeskus (Luke), Tuotantojärjestelmät, Tietotie 2C,31600 Jokioinen, \\ marketta.rinne@luke.fi \\ 3) nykyinen osoite: Eastman Chemical Company, Typpitie 1, 90620 Oulu, arjaseppala@eastman.com
}

Tutkimuksen tarkoituksena oli selvittää esikuivatun nurmisäilörehun säilöntäainekäsittelyn vaikutuksia loppukasvatettavien sonnien rehun syöntiin, kasvuun ja teurastuloksiin. Kontrollikäsittely tehtiin ilman säilöntäainetta (K). Tutkittavina aineina olivat AIV ÄSSÄ (AIV; valmistaja Eastman Chemical Company, sisältää muurahaishappoa, propionihappoa, ammoniumformiaattia ja kaliumsorbaattia) ja suolamuotoinen Safesil (SAF; valmistaja Salinity Agro, sisältää natriumbentsoaattia, kaliumsorbaattia ja natriumnitriittiä). Säilörehut korjattiin Luonnonvarakeskuksen (Luke) Siikajoen toimipisteessä kesällä 2014 timoteinurmen ensimmäisestä (17.-23.6.) ja toisesta (4.-6.8.) sadosta. Kasvustot niitettiin niittomurskaimella ja rehut korjattiin käärivällä paalaimella noin 24 h niiton jälkeen. Säilöntäainekäsittelyissä käytettiin valmistajan ilmoittamia annostelusuosituksia (AIV 5,8 ja SAF 3,4 $\mathrm{kg} \mathrm{t}^{-1}$ tuoretta ruohoa). Ruokintakokeessa oli 90 maitorotuista sonnia, jotka kasvatettiin viiden eläimen ryhmäkarsinoissa. Kokeen alkaessa sonnit olivat keskimäärin 251 vuorokauden ikäisiä ja painoivat 290 kg. Eläimet jaettiin satunnaisesti kolmelle eri koeruokinnalle, jotka perustuivat eri säilöntäkäsittelyillä korjattuihin säilörehuihin. Koeruokinnat toteutettiin seosrehuruokintana, jossa seoksen kuiva-aineesta $60 \%$ oli esikuivattua nurmisäilörehua ja 40\% litistettyä ohraa. Lisäksi huolehdittiin kivennäisten ja vitamiinien saannista. Sonnit saivat seosrehua vapaasti. Ensimmäisen sadon säilörehuja syötettiin 135 vuorokautta kokeen alussa ja toisen sadon säilörehuja kokeen jälkimmäinen puolisko (124 vuorokautta). Ensimmäisessä sadossa säilörehun D-arvo ja raakavalkuaispitoisuus olivat keskimäärin 699 ja $159 \mathrm{~g} \mathrm{~kg}^{-1} \mathrm{ka}$ ja toisessa sadossa 613 ja $175 \mathrm{~g} \mathrm{~kg}^{-1} \mathrm{ka}$. Säilöntäkäsittelyjen välillä ei ollut merkittäviä eroja rehun koostumuksessa tai rehuarvoissa. Kaikkien rehujen kuiva-ainepitoisuus oli suhteellisen korkea (350-400 g kg-1). Rehun säilönnällistä laatua säilöntäainekäsittelyt vaikuttivat hieman parantavan. AIV rehut näyttivät sisältävän vähemmän haihtuvia rasvahappoja ja ammoniumtyppeä kuin K rehut. Koekäsittelyjen välille ei muodostunut merkittäviä eroja rehun syöntiin tai ravintoaineiden saantiin keskimäärin kokeen aikana. Sonnien keskimääräinen nettopäiväkasvu oli $742 \mathrm{~g} \mathrm{pv}^{-1}$ eikä säilöntäainekäsittely vaikuttanut nettokasvuun. Sonnit teurastettiin keskimäärin 509 vuorokauden iässä, jolloin niiden teuraspaino oli 336 kg. Kontrollisäilörehua saaneiden sonnien ruhot olivat lihakkuudeltaan noin $5 \%$ heikompia kuin säilöntäainekäsiteltyä rehua saaneiden sonnien ruhot. Ruokintakäsittelyjen välille ei muodostunut eroja teurasprosentin tai ruhojen rasvaisuuden osalta. Koe osoitti, että kun nurmisäilörehu tehdään esikuivatusta raaka-aineesta, jonka kuiva-ainepitoisuus on yli $350 \mathrm{~g} \mathrm{~kg}^{-1}$, voi pyöröpaalisäilöntä onnistua myös ilman säilöntäaineiden käyttöä.

Asiasanat: naudanlihantuotanto, nurmisäilörehu, säilöntäaine, syönti, kasvu 


\section{Johdanto}

Hyvä säilörehu on naudan ruokinnan perusta. Käytännössä säilörehujen laatu kuitenkin vaihtelee huomattavasti enemmän kuin muiden rehuraaka-aineiden. Säilörehun laatuun vaikuttavat mm. kasvin kehitysvaihe korjuuhetkellä, korjuukerta (kevätkasvu tai jälkikasvu) ja säilönnän onnistuminen (Huhtanen ym. 2013). Säilörehun käymislaatu vaikuttaa naudan syömän rehun määrään ja siten eläimen käytettäväksi tulevien ravintoaineiden määriin ja suhteisiin (Huhtanen ym. 2007, Huuskonen ym. 2013a). Monissa tutkimuksissa säilörehun heikon käymislaadun on havaittu heikentävän nautojen syönti- ja kasvutuloksia (Keady ja Steen 1994, O’Kiely ja Moloney 1994, Agnew ja Carson 2000, Winters ym. 2001). Edellä mainitut kasvavien nautojen ruokintakokeet on kuitenkin toteutettu esikuivaamattomilla (kuivaainepitoisuus 167-230 g kg${ }^{-1}$ ) säilörehuilla, kun valtaosa nurmisäilörehusta korjataan nykyään Suomessa esikuivattuna. Tämän tutkimuksen tarkoituksena oli selvittää esikuivatun nurmisäilörehun säilöntäainekäsittelyn vaikutuksia loppukasvatettavien sonnien rehujen syöntiin, kasvuun ja teurastuloksiin.

\section{Aineisto ja menetelmät}

Ruokintakoe suoritettiin Luonnonvarakeskuksen (Luke) Siikajoen toimipisteen tutkimuspihatossa, jonne hankittiin vuoden 2014 lopulla $90 \mathrm{kpl}$ maitorotuisia (45 holstein +45 ayrshire) välikasvatettuja sonnivasikoita. Kokeen alussa sonnit painoivat keskimäärin $290( \pm 24.5) \mathrm{kg}$ ja olivat 251 ( \pm 10.0$)$ vuorokauden ikäisiä. Sonnit kasvatettiin viiden eläimen ryhmäkarsinoissa, joiden pituus oli $10 \mathrm{~m}$ ja leveys 5 m. Karsinassa oli siten tilaa $10 \mathrm{~m}^{2}$ eläintä kohden. Karsina-alue muodostui lantakäytävästä ja kuivitetusta makuualueesta. Makualueen koko oli $5 \times 5 \mathrm{~m}$, jolloin eläintä kohti oli $5 \mathrm{~m}^{2}$ kuivitettua makuualuetta. Kokeen alussa sonnit jaettiin rodun ja elopainon perusteella kolmelle koeruokinnalle, jolloin kullekin koeruokinnalle tuli 15 ayrshire- ja 15 holstein-sonnia (6 karsinaa ja 30 sonnia / koeruokinta).

Koesäilörehut korjattiin Luonnonvarakeskuksen Siikajoen toimipisteessä kesällä 2014 timoteinurmen ensimmäisestä (17.-23.6.) ja toisesta (4.-6.8.) sadosta. Kasvustot niitettiin niitto-murskaimella (Elho HNM 280 P), karhotus tehtiin yksiroottorisella karhottimella (Pöttinger) ja rehut korjattiin käärivällä paalaimella (Machale Fusion 3) noin 24 h niiton jälkeen. Paaliverkkona oli Netex S2S, jota laitettiin 3 kierrosta paalin ympärille, jotta paalin tiiviys varmasti säilyi. Käärintämuovina käytettiin Duo 7 Plus XL muovia. Paalin ympärille laitettiin 6 kerrosta muovia.

Kontrollikäsittelyn paalit tehtiin ilman säilöntäainetta (K). Tutkittavina säilöntäaineina olivat AIV ÄSSÄ (AIV; valmistaja Eastman Chemical Company, muurahaishappoa, propionihappoa, ammoniumformiaattia ja kaliumsorbaattia) ja suolamuotoinen Safesil (SAF; valmistaja Salinity Agro, natriumbentsoaattia, kaliumsorbaattia ja natriumnitriittiä). Kokeessa käytettiin valmistajan ilmoittamia annostelusuosituksia (toteutuneet käyttömäärät AIV 5.8 ja SAF $3.4 \mathrm{~kg} \mathrm{t}^{-1}$ tuoretta ruohoa).

Kukin säilöntäainekäsittely (K, AIV, SAF) muodosti oman koeruokintansa. Ruokinta tapahtui seosrehuruokintana perustuen vapaaseen rehun saantiin. Kaikilla koekäsittelyillä seosrehussa oli nurmisäilörehua $60 \%$ rehuannoksen kuiva-aineesta ja väkirehuna litistettyä ohraa $40 \%$ rehuannoksen kuiva-aineesta. Lisäksi annettiin tarvittavat kivennäiset ja vitamiinit. Koesuunnitelman mukaiset seosrehut valmistettiin seosrehuvaunulla (Trioliet, $10 \mathrm{~m}^{3}$ ), josta rehu jaettiin ruokintakaukaloihin (GrowSafe Systems). Jokaisessa karsinassa oli kaksi ruokintakaukaloa, jotka mahdollistivat yksilökohtaisen rehun kulutuksen seurannan (eläinten automaattinen tunnistus elektronisten korvamerkkien kautta).

Ruokintakoe aloitettiin tammikuussa 2015. Ensimmäisen korjuukerran säilörehuja syötettiin 4,5 kuukauden ajan (135 vuorokautta) kokeen alussa ja toisen korjuukerran rehuja kokeen jälkimmäinen puolisko (124 vuorokautta). Näin ollen koko ruokintakoe kesti yhteensä 259 vuorokautta. Seosrehua tehtäessä säilörehuista otettiin näytteitä, jotka pakastettiin ja yhdistettiin jokaisen ruokintajakson (kesto keskimäärin 28 vrk) analyysinäytteeksi. Ohrasta kerättiin näytteet jokaisesta rehuerästä ja yhdistettiin eräkohtaisiksi analyysinäytteiksi. Rehunäytteistä määritettiin kuiva-aine, tuhka, raakavalkuainen, kuitu, D-arvo, muuntokelpoinen energia, OIV ja PVT sekä säilörehujen syönti-indeksi ja säilönnällinen laatu Huuskosen ym. (2017) kuvaamin menetelmin.

Sonnien kasvua seurattiin punnitsemalla eläimet kahtena peräkkäisenä päivänä kokeen alussa, kokeen puolivälissä säilörehun vaihtuessa ja kokeen lopussa. Punnitustuloksena käytettiin kahden punnituskerran keskiarvoa. Sonnien elopainon kasvu (päiväkasvu) laskettiin loppuelopainon ja kokeen alun elopainon erotuksena jaettuna kasvatuspäivillä. Sonnit teurastettiin Atria Oy:n Kauhajoen teurastamossa. Teuraspainotavoite oli $335 \mathrm{~kg}$. Teurastus tapahtui yleisten teurastuskäytäntöjen mukaan (EC 2006). Nettokasvu laskettiin teuraspainon ja kokeen alun ruhopainon erotuksena jaettuna 
kasvatuspäivillä. Ruhopainona kokeen alussa käytettiin arviota elopaino $\times 0,5$. Teurasprosentti saatiin jakamalla eläimen ruhopaino kokeen lopun elopainolla ja kertomalla sadalla. Ruhon lihakkuus määriteltiin EUROP-luokituksella, jossa E tarkoittaa lihakkuudeltaan erinomaista ja P lihakkuudeltaan heikkoa ruhoa. Luokkia oli kaiken kaikkiaan 15 (E+, E, E-, U+, U, U-, R+, R, R-, O+, O, O-, P+, P, P-). Tilastollista käsittelyä varten luokat numeroitiin numeroilla 1-15. Rasvaluokitus tehtiin asteikolla 1-5, jossa 1 tarkoittaa vähärasvaista ja 5 erittäin rasvaista ruhoa (EC 2006).

Tilastollinen käsittely tehtiin SAS-ohjelmiston (versio 9.4, SAS Institute Inc.,Cary, NC, USA) GLM-proseduurilla. Tuloksia testattaessa käytettiin seuraavaa tilastollista mallia: $\mathrm{y}_{\mathrm{ijkl}}=\mu+\alpha_{\mathrm{i}}+\gamma_{\mathrm{j}}+$ $(\alpha \times \gamma)_{\mathrm{ij}}+\theta_{\mathrm{ijl}}+\beta \mathrm{x}_{\mathrm{ijk}}+\mathrm{e}_{\mathrm{ijkl}}$. Koemallissa $\mu$ on yleiskeskiarvo ja $\mathrm{e}_{\mathrm{ijkl}}$ on virhetermi. $\alpha_{\mathrm{i}}$ on säilöntäainekäsittelyn (K, AIV, SAF) kiinteä vaikutus, $\gamma_{\mathrm{j}}$ on rodun $(\mathrm{Ay}, \mathrm{Hol})$ kiinteä vaikutus ja $(\alpha \times \gamma)_{\mathrm{ij}}$ on säilöntäainekäsittelyn ja rodun yhdysvaikutus. $\theta_{\mathrm{ijl}}$ on karsinan satunnaisvaikutus. Eläinten elopainoa kokeen alussa käytettiin kovariaattina $\left(\beta \mathrm{x}_{\mathrm{ijk}}\right)$ mallissa testattaessa syöntiä, kasvua ja rehun hyväksikäyttöä kuvaavia muuttujia. Teurastulosten (teurasprosentti, ruhon lihakkuus, ruhon rasvaisuus) osalta mallissa käytettiin kovariaattina teuraspainoa. Ruokintakokeen koekäsittelyjen väliset tilastolliset erot testattiin ortogonaalisilla kontrasteilla: 1) Kontrolli vs. säilöntäainekäsittelyt, 2) SAF vs. AIV ja 3) rodun vaikutus: ayrshire vs. holstein. Koska säilöntäainekäsittelyn ja rodun yhdysvaikutukset eivät olleet tilastollisesti merkitseviä, tulokset esitetään ainoastaan säilöntäainekäsittelyn ja rodun päävaikutusten osalta.

\section{Tulokset}

\section{Rehujen koostumus ja säilönnällinen laatu}

Ensimmäisen korjuukerran säilörehujen kuiva-ainepitoisuus oli keskimäärin $362 \mathrm{~g} \mathrm{~kg}^{-1}$ ja toisen korjuukerran säilörehuilla vastaavasti $389 \mathrm{~g} \mathrm{~kg}^{-1}$ (Taulukko 1). Ensimmäisen niiton säilörehu oli sulavampaa (D-arvo 699 vs. $613 \mathrm{~g} \mathrm{~kg}^{-1} \mathrm{ka}$ ) ja sisälsi hieman vähemmän raakavalkuaista (159 vs. $175 \mathrm{~g} \mathrm{~kg}^{-1} \mathrm{ka}^{\text {) kuin }}$ toisen niiton säilörehu. Niittokertojen välinen ero näkyi myös säilörehun syönti-indeksissä, joka oli ensimmäisen niiton rehulla selvästi korkeampi kuin toisen niiton rehulla (Taulukko 1).

Taulukko 1. Koerehujen koostumus ja säilönnällinen laatu.

\begin{tabular}{|c|c|c|c|c|c|c|c|}
\hline & \multicolumn{3}{|c|}{ Säilörehu 1. niitto } & \multicolumn{3}{|c|}{ Säilörehu 2. niitto } & \multirow[t]{2}{*}{ Ohra } \\
\hline & $\mathrm{K}$ & SAF & AIV & $\mathrm{K}$ & SAF & AIV & \\
\hline Näytemäärä, kpl & 5 & 5 & 5 & 4 & 4 & 4 & 5 \\
\hline Kuiva-aine (ka), g kg-1 & 356 & 358 & 371 & 390 & 399 & 378 & 882 \\
\hline Tuhka, g kg-1 ka & 67 & 64 & 58 & 75 & 79 & 74 & 29 \\
\hline Raakavalkuainen, g kg-1 ka & 162 & 154 & 161 & 177 & 174 & 173 & 122 \\
\hline Kuitu, g kg-1 ka & 528 & 542 & 535 & 564 & 578 & 564 & 211 \\
\hline Muuntokelpoinen energia, MJ kg-1 ka & 11.2 & 11.1 & 11.2 & 9.9 & 9.7 & 9.9 & 13.2 \\
\hline OIV, $\mathrm{g} \mathrm{kg}^{-1} \mathrm{ka}$ & 88 & 87 & 88 & 85 & 84 & 85 & 98 \\
\hline PVT, g kg ${ }^{-1} \mathrm{ka}$ & 31 & 24 & 29 & 51 & 51 & 47 & -25 \\
\hline D-arvo, $\mathrm{g} \mathrm{kg}^{-1} \mathrm{ka}$ & 698 & 695 & 703 & 618 & 604 & 617 & \\
\hline Säilörehun syönti-indeksi & 110 & 110 & 114 & 95 & 93 & 97 & \\
\hline \multicolumn{8}{|l|}{ Säilörehun säilönnällinen laatu } \\
\hline $\mathrm{pH}$ & 4.24 & 4.28 & 4.27 & 4.59 & 4.74 & 4.52 & \\
\hline Maitohappo, $\mathrm{g} \mathrm{kg}^{-1} \mathrm{ka}$ & 55.6 & 49.3 & 37.4 & 39.8 & 33.1 & 27.2 & \\
\hline Muurahaishappo, $\mathrm{g} \mathrm{kg}^{-1} \mathrm{ka}$ & 0.1 & 0.1 & 3.6 & 0.1 & 0.1 & 5.4 & \\
\hline Sokerit, $\mathrm{g} \mathrm{kg}^{-1} \mathrm{ka}$ & 79.4 & 94.8 & 129.5 & 53.5 & 53.7 & 73.3 & \\
\hline Etanoli, g kg-1 ka & 8.8 & 7.1 & 6.8 & 3.8 & 2.5 & 2.6 & \\
\hline Haihtuvat rasvahapot, $\mathrm{g} \mathrm{kg}^{-1} \mathrm{ka}$ & 14.6 & 12.7 & 11.1 & 14.5 & 15.7 & 10.9 & \\
\hline Etikkahappo, $\mathrm{g} \mathrm{kg}^{-1} \mathrm{ka}$ & 13.5 & 11.9 & 9.1 & 13.5 & 14.7 & 8.3 & \\
\hline Propionihappo, g kg-1 ka & 0.41 & 0.33 & 1.44 & 0.30 & 0.42 & 1.92 & \\
\hline Voihappo, g kg-1 ka & 0.35 & 0.30 & 0.29 & 0.36 & 0.29 & 0.34 & \\
\hline Ammonium $\mathrm{N}, \mathrm{g} \mathrm{kg}^{-1} \mathrm{~N}$ & 54.8 & 52.4 & 47.5 & 66.2 & 71.2 & 56.6 & \\
\hline
\end{tabular}


Koekäsittelyjen välillä ei ollut merkittäviä eroja kemiallisessa koostumuksessa tai rehuarvoissa (Taulukko 1). Rehun säilönnällistä laatua säilöntäainekäsittelyt vaikuttivat hieman parantavan. Varsinkin AIV-Ässällä säilötty rehu näytti sisältävän vähemmän haihtuvia rasvahappoja ja ammoniumtyppeä kuin ilman säilöntäainetta tehty kontrollirehu.

\section{Eläintuotos}

Koe kesti 259 vuorokautta, ja sonnit olivat teurastettaessa keskimäärin 509 vuorokauden ikäisiä ja painoivat keskimäärin 336 kg (Taulukko 2). Rotu ja ruokinta eivät vaikuttaneet eläinten teuraspainoon. Rodulla ei ollut myöskään vaikutusta sonnien rehun syöntiin tai ravintoaineiden saantiin kokeen aikana. Sen sijaan säilöntäkäsittely näytti vaikuttavan rehun syöntiin kokeen ensimmäisellä puolikkaalla, jolloin syötössä olivat ensimmäisen niiton säilörehut. Kontrollisäilörehua saaneiden sonnien rehun syönti ja energian saanti oli kokeen ensimmäisen puoliskon aikana keskimäärin $7 \%$ suuremmat $(p=0.002)$ kuin SAF- ja AIV-säilörehua saaneilla sonneilla. Vastaavaa eroa ei havaittu kokeen jälkimmäisellä puoliskolla (Taulukko 2). SAF- ja AIV-ruokintojen välillä ei havaittu eroja rehun syönnissä tai energian saannissa.

Taulukko 2. Sonnien rehun syönti sekä kasvu- ja teurastulokset ruokintakokeessa.

\begin{tabular}{|c|c|c|c|c|c|c|c|c|c|}
\hline & \multicolumn{3}{|c|}{ Ruokinta } & \multicolumn{2}{|c|}{ Rotu } & \multirow[t]{2}{*}{ SEM } & \multicolumn{3}{|c|}{$p$-arvot } \\
\hline & $\mathrm{K}$ & SAF & AIV & AY & $\mathrm{HO}$ & & 1 & 2 & 3 \\
\hline Eläinmäärä, kpl & 30 & 28 & 29 & 45 & 42 & - & - & - & - \\
\hline Teurasikä, pv & 508 & 511 & 509 & 510 & 508 & 1.7 & 0.35 & 0.43 & 0.47 \\
\hline \multicolumn{10}{|l|}{ Kuiva-aineen (ka) syönti, kg pv-1 } \\
\hline Jakso 1 (135 pv, 1. niiton säilörehu) & 9.51 & 9.03 & 8.76 & 9.18 & 9.06 & 0.136 & 0.43 & 0.002 & 0.15 \\
\hline Jakso 2 (124 pv, 2. niiton säilörehu) & 11.07 & 11.46 & 11.29 & 11.41 & 11.15 & 0.209 & 0.30 & 0.26 & 0.57 \\
\hline Koko koe (259 pv) & 10.23 & 10.18 & 9.96 & 10.21 & 10.03 & 0.152 & 0.32 & 0.39 & 0.32 \\
\hline \multicolumn{10}{|l|}{ Energian saanti, $\mathrm{MJ} \mathrm{pv}^{-1}$} \\
\hline Jakso 1 & 114 & 108 & 106 & 110 & 109 & 1.6 & 0.43 & 0.002 & 0.24 \\
\hline Jakso 2 & 125 & 128 & 127 & 128 & 125 & 2.3 & 0.30 & 0.35 & 0.89 \\
\hline Koko koe & 119 & 117 & 116 & 119 & 116 & 1.8 & 0.32 & 0.27 & 0.54 \\
\hline \multicolumn{10}{|l|}{ Raakavalkuaisen saanti, g pv-1 } \\
\hline Jakso 1 & 1412 & 1297 & 1292 & 1344 & 1328 & 19.9 & 0.45 & $<0.001$ & 0.92 \\
\hline Jakso 2 & 1686 & 1732 & 1690 & 1723 & 1683 & 31.5 & 0.30 & 0.53 & 0.37 \\
\hline Koko koe & 1539 & 1501 & 1480 & 1520 & 1493 & 22.7 & 0.32 & 0.11 & 0.53 \\
\hline \multicolumn{10}{|l|}{ Elopaino, kg } \\
\hline Kokeen alussa & 287 & 295 & 290 & 289 & 293 & 2.2 & 0.63 & 0.38 & 0.49 \\
\hline Säilörehun vaihtuessa & 503 & 496 & 496 & 500 & 498 & 3.9 & 0.67 & 0.24 & 0.75 \\
\hline Kokeen lopussa & 650 & 641 & 636 & 643 & 642 & 5.6 & 0.90 & 0.17 & 0.43 \\
\hline \multicolumn{10}{|l|}{ Elopainon kasvu, g pv ${ }^{-1}$} \\
\hline Jakso 1 & 1601 & 1490 & 1524 & 1558 & 1519 & 26.4 & 0.23 & 0.01 & 0.43 \\
\hline Jakso 2 & 1185 & 1167 & 1130 & 1157 & 1166 & 24.0 & 0.74 & 0.27 & 0.29 \\
\hline Koko koe & 1408 & 1340 & 1341 & 1371 & 1355 & 20.5 & 0.52 & 0.02 & 0.94 \\
\hline Ruhopainon kasvu, g pv ${ }^{-1}$ & 747 & 736 & 741 & 750 & 732 & 14.8 & 0.33 & 0.64 & 0.81 \\
\hline \multicolumn{10}{|l|}{ Rehun hyväksikäyttö (koko koe) } \\
\hline Kg ka rehua $\mathrm{kg}^{-1}$ elopainon kasvua & 7.23 & 7.60 & 7.43 & 7.45 & 7.40 & 0.186 & 0.76 & 0.36 & 0.43 \\
\hline MJ kg-1 elopainon kasvua & 84.5 & 87.3 & 86.5 & 86.8 & 85.6 & 2.15 & 0.76 & 0.44 & 0.58 \\
\hline Kg ka rehua $\mathrm{kg}^{-1}$ ruhopainon kasvua & 13.69 & 13.83 & 13.44 & 13.61 & 13.70 & 0.408 & 0.98 & 0.76 & 0.35 \\
\hline MJ kg-1 ruhopainon kasvua & 159.3 & 159.0 & 156.5 & 158.7 & 158.5 & 4.73 & 0.99 & 0.66 & 0.46 \\
\hline \multicolumn{10}{|l|}{ Teurastulokset } \\
\hline Teuraspaino, kg & 336 & 336 & 333 & 337 & 334 & 3.7 & 0.45 & 0.84 & 0.54 \\
\hline Teurasprosentti, g kg-1 & 517 & 524 & 524 & 524 & 519 & 2.9 & 0.33 & 0.16 & 0.95 \\
\hline Ruhon lihakkuus, EUROP & 4.77 & 5.11 & 5.00 & 5.13 & 4.79 & 0.083 & 0.004 & 0.01 & 0.29 \\
\hline Ruhon rasvaisuus, EUROP & 2.60 & 2.43 & 2.38 & 2.42 & 2.51 & 0.102 & 0.56 & 0.21 & 0.79 \\
\hline
\end{tabular}

SEM = keskiarvon keskivirhe.

Ruokinnat: Kontrollisäilörehu (K) tehtiin ilman säilöntäainetta. Tutkittavina aineina olivat muurahaishappopohjainen AIV ÄSSÄ (AIV) ja suolamuotoinen Safesil (SAF).

Rotu: $\mathrm{AY}=$ ayrshire, $\mathrm{HO}=$ holstein.

P-arvot: 1) kontrolli vs. säilöntäainekäsittelyt, 2) SAF vs. AIV ja 3) rodun vaikutus: ayrshire vs. holstein. 
Rotu ei vaikuttanut sonnien kasvutuloksiin eikä rehun hyväksikäyttöön. Sonnien elopainon kasvu kokeen aikana oli keskimäärin $1363 \mathrm{~g} \mathrm{pv}^{-1}$ ja ruhopainon kasvu $741 \mathrm{~g} \mathrm{pv}^{-1}$. Säilöntäkäsittely ei vaikuttanut sonnien ruhopainon kasvuun, mutta kontrollisäilörehua saaneiden sonnien elopainon kasvu oli kokeen ensimmäisen puoliskon aikana 6\% ( $p=0.01)$ ja koko kokeen ajalle laskettuna $5 \%(p=0.02)$ suurempi kuin SAF- ja AIV-säilörehua saaneilla sonneilla keskimäärin. Säilöntäkäsittely ei vaikuttanut rehun hyväksikäyttöön (Taulukko 2).

Sonnien teurasprosentti oli keskimäärin $522 \mathrm{~g} \mathrm{~kg}^{-1}$, ruhon lihakkuusluokka 4,96 ja ruhon rasvaisuusluokka 2,46. Rotu ja säilöntäainekäsittely eivät vaikuttaneet teurasprosenttiin eivätkä ruhon rasvaisuuteen. Sen sijaan ruhon lihakkuusluokkaan koekäsittelyt vaikuttivat tilastollisesti merkitsevästi. Kontrollisäilörehua saaneiden sonnien ruhot olivat lihakkuudeltaan noin 5\% heikompia kuin säilöntäainekäsiteltyä rehua saaneiden sonnien ruhot $(p=0.015)$. Ayrshire-sonnien ruhot olivat lihakkuudeltaan $7 \%$ parempia kuin holstein-sonnien ruhot $(p=0.004)$.

\section{Tulosten tarkastelu \\ Rodun vaikutukset}

Tutkittujen rotujen välillä havaittiin vain vähäisiä eroja, eivätkä rodun ja säilöntäainekäsittelyn väliset yhdysvaikutukset olleet tilastollisesti merkitseviä, joten rodun vaikutuksia tarkastellaan vain hyvin lyhyesti. Merkittävin rotujen välillä havaittu ero oli ruhojen lihakkuudessa, joka oli ayrshire-sonneilla selvästi holstein-sonneja parempi. Vastaava rotujen välinen ero on havaittu valtakunnallisessa teurasaineistossa, jossa ayrshire-sonnien lihakkuusluokka oli 14\% parempi kuin holstein-sonneilla (Huuskonen 2014). Myös teurashiehojen osalta ayrshire-ruhot ovat osoittautuneet holsteineja lihakkaammiksi (Huuskonen ym. 2013b). Valtakunnallisessa teurasaineistossa holstein-sonnien ruhopainon kasvu oli hieman suurempi ja ruhojen rasvaisuusluokka hieman matalampi kuin ayrshire-sonneilla (Huuskonen 2014), mutta nyt raportoitavassa kokeessa vastaavia eroja rotujen välillä ei havaittu.

\section{Säilöntäainekäsittelyn vaikutukset}

Kaikki koesäilörehut olivat säilönnälliseltä laadultaan hyviä, mikä osaltaan vaikutti siihen, että koekäsittelyjen välille ei muodostunut kovinkaan paljon merkittäviä eroja eläinten tuotantotuloksissa. Koesäilörehujen suhteellisen korkea kuiva-ainepitoisuus oli todennäköisesti syynä siihen, että myös kontrollisäilörehu oli säilönnälliseltä laadultaan hyvää ja erot säilörehujen laadussa jäivät pieniksi. Rinne ym. (2018) selvittivät erillisessä tarkastelussa tämän kokeen osanäytteiden avulla rehujen eroja ja totesivat AIV:n rajoittaneen merkitsevästi säilörehun käymistä. Säilöntäaineiden käyttö myös pidensi rehujen aerobista stabiilisuutta, millä on merkitystä työnkäytön ja rehuhävikin pienentämisessä.

Useissa tutkimuksissa on todettu, että säilörehun esikuivaus yleensä parantaa säilönnän onnistumisen edellytyksiä (Heikkilä ym. 2010, Jaakkola ym. 2010, Seppälä ym. 2016). Yhdenmukaisesti nyt raportoivan kokeen kanssa Heikkilä ym. (2010) havaitsivat, että rehun kuiva-ainepitoisuuden ollessa yli $300 \mathrm{~g} \mathrm{~kg}^{-1}$ suhteellisen hyvä säilönnällinen laatu saavutettiin myös ilman säilöntäaineiden käyttöä. Toisaalta Knicky ja Spörndly $(2009,2011)$ havaitsivat, että vastaava SAF-käsittely kuin tässä kokeessa paransi rehun säilönnällistä laatua sekä matalissa että korkeissa kuiva-ainepitoisuuksissa. Huhtasen ym. (2013) mukaan muurahaishappolisäys laskee tehokkaasti rehun pH:ta ja rajoittaa käymistä, mikä näkyy matalampana kokonaishappojen ja ammoniumtypen pitoisuuksina ja korkeampana jäännössokerin pitoisuutena verrattuna ilman säilöntäainetta tehtyyn rehuun. Tämä oli jossakin määrin havaittavissa myös nyt raportoitavassa tutkimuksessa, varsinkin ensimmäisen niiton rehujen osalta. Myös Seppälä ym. (2013) havaitsivat, että muurahaishappolisäys voi rajoittaa käymistä myös esikuivatulla (kuiva-ainepitoisuus 340-360 $\mathrm{g} \mathrm{kg}^{-1}$ ) säilörehuilla.

On hankala löytää selkeää selitystä sille, miksi sonnit söivät kokeen ensimmäisen puoliskon aikana enemmän rehua kontrolliruokinnalla kuin säilöntäainekäsittelyillä. Vaikka säilörehun syönti-indeksi oli AIV-säilörehulla korkeampi kuin K-säilörehulla, sonnien kuiva-aineen syönti oli K-ruokinnalla suurempaa. Teoreettisesti tarkasteltuna AIV-rehun K-rehua korkeampi propionihappopitoisuus voisi osaltaan selittää pienempää rehun syöntiä, sillä tutkimuksissa säilörehun propionihappopitoisuuden on havaittu vaikuttavan syöntiin voimakkaammin kuin muiden haihtuvien rasvahappojen (Huhtanen ym. 2002, Krizsan ja Randby 2007, Huuskonen ym. 2013). On kuitenkin todennäköistä, että nämä aiemmin havaitut tulokset kuvaavat ennemminkin säilörehun käymisprosessin voimakkuutta kuin yksistään propionihapon vaikutusta. Myös Huhtanen ym. (2002) pitivät epätodennäköisenä, että propionihapolla 
itsessään suhteellisen pieninä pitoisuuksina olisi suoraa vaikutusta syöntimääriin. Useissa aiemmissa kasvavien nautojen ruokintakokeissa säilöntäainelisäys on lisännyt säilörehun syöntiä (Keady ja Steen 1994, O’Kiely ja Moloney 1994, Agnew ja Carson 2000, Winters ym. 2001). Esimerkiksi Agnew ja Carson (2000) havaitsivat, että säilöntäaineen lisäys lisäsi härkien säilörehun syöntiä 21\% ilman säilöntäainetta tehtyyn kontrollisäilörehuun verrattaessa. Nyt raportoitavan ja aiempien kokeiden väliset erot voivat johtua eroista kuiva-ainepitoisuudessa, sillä edellä mainitut kokeet toteutettiin esikuivaamattomilla (kuiva-ainepitoisuus 167-230 g kg-1) säilörehuilla, joissa säilöntäaine paransi selvästi säilörehun käymislaatua kontrollirehuun verrattuna.

Kontrolliruokinnalla olleiden sonnien hieman suurempi rehun syönti näkyi myös lisääntyneenä energian saantina, mikä todennäköisesti oli suurin syy elopainon kasvussa havaittuihin eroihin. Energian saannin on osoitettu olevan merkittävin kasvuun vaikuttava ruokinnallinen tekijä kasvavilla naudoilla (Huuskonen ja Huhtanen 2015). Ruhopainon kasvussa ei kuitenkaan havaittu eroja koeruokintojen välillä. Aiemmat tulokset säilöntäainekäsittelyiden vaikutuksista lihanautojen kasvuun ovat ristiriitaisia. Joissakin kokeissa säilöntäainelisäyksen on havaittu parantavan sekä elopainon että ruhopainon kasvua, kun ruokinnassa ei ole käytetty väkirehulisää (Agnew ja Carson 2000). Kuitenkaan 1.5 kg:n väkirehulisää käytettäessä ruhopainon kasvussa ei havaittu eroja koekäsittelyjen välillä, vaikka säilöntäainelisäys lisäsi säilörehun syöntimäärää (Agnew ja Carson 2000). O’Kiely ja Moloney (1994) havaitsivat ensimmäisessä osakokeessaan muurahaishappolisäyksen lisäävän nautojen elopainon kasvua ilman säilöntäainetta tehtyyn kontrollisäilörehuun verrattaessa, mutta toisessa osakokeessa vastaavaa ei havaittu. Keady ja Steen (1994) puolestaan raportoivat ruhopainon kasvun parantuneen, kun ruokinnassa käytettiin muurahaishapolla säilöttyä säilörehua ilman säilöntäainetta tehdyn kontrollisäilörehun sijaan. Erilaiset tulokset kokeiden välillä voivat selittyä säilörehun kuiva-ainepitoisuuden lisäksi väkirehun määrällä. Säilörehun laatu korostuu, jos sitä käytetään ainoana rehuna tai ruokinnassa käytetään hyvin pieniä väkirehumääriä.

Myös Agnew ja Carson (2000) havaitsivat ruhojen lihakkuuden olleen parempi, kun ruokinnassa käytettiin muurahaishapolla säilöttyä säilörehua kontrollisäilörehun sijasta. Heidän kokeessaan erot lihakkuudessa selittyvät kuitenkin todennäköisesti osittain myös eroilla eläinten teuraspainoissa. Happosäilötyllä rehulla ruokitut eläimet olivat painavampia kuin kontrolliruokinnalla olleet (Agnew ja Carson 2000), ja teuraspainon lisääntymisen on havaittu korreloivan positiivisesti ruhon lihakkuuden kanssa (Kempster ym. 1988, Keane ja Allen 1998). O’Kiely ja Moloney (1994) eivät havainneet säilöntäainekäsittely vaikuttavan ruhojen lihakkuuteen.

\section{Johtopäätökset}

Koe osoitti, että kun nurmisäilörehu tehdään hyvissä olosuhteissa esikuivatusta raaka-aineesta, jonka kuiva-ainepitoisuus on selkeästi yli 30\%, voi pyöröpaalisäilöntä onnistua kohtuullisen hyvin myös ilman säilöntäaineiden käyttöä. Kuitenkin esimerkiksi märissä olosuhteissa epäonnistumisen riski on suuri. Säilöntäaineen käyttämättä jättämisellä voidaan saavuttaa hieman kustannussäästöä, mutta tällöin otetaan myös riski, että korjattu rehu pilaantuu, säilöntätappiot ja rehuhävikki kasvavat ja rehun tuotantovaikutus heikkenee. On huomattava, että tässä kokeessa tavoiteltuun kuiva-ainepitoisuuteen päästiin noin 1 vrk esikuivausajalla. Aina säät eivät suosi rehunkorjaajaa, ja pitkittynyt esikuivausaika pellolla aiheuttaa tyypillisesti tappioita kaikkein sulavimmissa ravintoaineissa. Rehun tekeminen ilman säilöntäainetta ei näin ollen sovellu yleistavoitteeksi vaan paremminkin mahdollisuudeksi, jota voi hyödyntää olosuhteiden ollessa suotuisat. Naudankasvatuksen lopputuloksessa säilöntäaineen käyttö näkyi tässä kokeessa parantuneena ruhon lihakkuutena, vaikkei eroja teuraspainossa tai rasvaisuudessa ollut eri säilöntäkäsittelyjen välillä.

\section{Kiitokset}

Tutkimus toteutettiin osana NautaNurmi-hanketta, jota rahoitettiin Euroopan maaseudun kehittämisen maatalousrahastosta. Tuki myönnettiin Pohjois-Pohjanmaan ELY-keskuksen kautta. NautaNurmi-hankkeen yritysrahoittajina toimivat Eastman Chemical Company, Ab Hanson \& Möhring, Yara Suomi Oy ja Nordkalk Oy Ab. 


\section{Kirjallisuus}

Agnew, R.E. \& Carson, M.T. 2000. The effect of a silage additive and level of concentrate supplementation on silage intake, animal performance and carcass characteristics of finishing beef cattle. Grass and Forage Science 55: $114-124$.

EC 2006. Council Regulation (EC) No 1183/2006 of 24 July 2006 concerning the Community scale for the classification of carcasses of adult bovine animals. The Official Journal of the European Union L, 214: 1-6.

Heikkilä, T., Saarisalo, E., Taimisto, A-M. \& Jaakkola, S. 2010. Effects of dry matter and additive on wilted bale silage quality and milk production. Grassland Science in Europe 15: 500-502.

Huhtanen, P., Khalili, H., Nousiainen, J. I., Rinne, M., Jaakkola, S., Heikkilä, T. \& Nousiainen, J. 2002. Prediction of the relative intake potential of grass silage by dairy cows. Livestock Production Science 73: 111130.

Huhtanen, P., Jaakkola, S. \& Nousiainen, J. 2013. An overview of silage research in Finland: from ensiling innovation to advances in dairy cow feeding. Agricultural and Food Science 22: 35-56.

Huhtanen, P., Rinne, M. \& Nousiainen, J. 2007. Evaluation of the factors affecting silage intake of dairy cows; a revision of the relative silage dry matter intake index. Animal 1: 758-770.

Huuskonen, A. 2014. A comparison of Nordic Red, Holstein-Friesian and Finnish native cattle bulls for beef production and carcass traits. Agricultural and Food Science 23: 159-164.

Huuskonen, A. \& Huhtanen, P. 2015. The development of a model to predict BW gain of growing cattle fed grass silage-based diets. Animal 9: 1329-1340.

Huuskonen, A., Huhtanen, P. \& Joki-Tokola, E. 2013a. The development of a model to predict feed intake by growing cattle. Livestock Science 158: 74-83.

Huuskonen, A., Pesonen, M., Kämäräinen, H. \& Kauppinen, R. 2013b. Comparison of the growth and carcass traits between dairy and dairy $\times$ beef breed crossbred heifers reared for beef production. Journal of Animal and Feed Sciences 22: 262-271.

Huuskonen, A., Seppälä, A. \& Rinne, M. 2017. Effects of silage additives on intake, live-weight gain and carcass traits of growing and finishing dairy bulls fed pre-wilted grass silage and barley grain-based ration. Journal of Agricultural Science 155: 1342-1352.

Jaakkola, S., Saarisalo, E. \& Heikkilä, T. 2010. Aerobic stability and fermentation quality of round bale silage treated with inoculants or propionic acid. Grassland Science in Europe 15: 503-505.

Keady, T.W.J. \& Steen, R.W.J. 1994. Effects of treating low dry-matter grass with a bacterial inoculant on the intake and performance of beef cattle and studies on its mode of action. Grass and Forage Science 49: 438-446.

Keane, M.G. \& Allen, P. 1998. Effects of production system intensity on performance, carcass composition and meat quality of beef cattle. Livestock Production Science 56: 203-214.

Kempster, A. J., Cook, G.L. \& Southgate, J. R. 1988. Evaluation of British Friesian, Canadian Holstein and beef breed $\times$ British Friesian steers slaughtered over a commercial range of fatness from 16-month and 24- month beef production systems. 2. Carcass characteristics, and rate and efficiency of lean gain. Animal Production 46: 365-378.

Knicky, M. \& Spörndly, R. 2009. Sodium benzoate, potassium sorbate and sodium nitrite as silage additives. Journal of the Science of Food and Agriculture 89: 2659-2667.

Knicky, M. \& Spörndly, R. 2011. The ensiling capability of a mixture of sodium benzoate, potassium sorbate, and sodium nitrite. Journal of Dairy Science 94: 824-831.

Krizsan, S. J. \& Randby, Å. T. 2007. The effect of fermentation quality on the voluntary intake of grass silage by growing cattle fed silage as the sole feed. Journal of Animal Science 85: 984-996.

O’Kiely, P. \& Moloney, A.P. 1994. Silage characteristics and performance of cattle offered grass silage made without an additive, with formic acid or with a partially neutralized blend of aliphatic organic acids. Irish Journal of Agricultural and Food Research 33: 25-39.

Rinne, M., Jalava, T., Kuoppala, K., Seppälä, A., Huuskonen, A. 2018. Kemialliset säilöntäaineet esikuivatun nurmisäilörehun säilönnässä. Maataloustieteen Päivät 2018. Saatavilla:www.smts.fi.

Seppälä, A., Tsitko, I., Ervasti, S., Miettinen, H., Salakka, A. \& Rinne, M. 2013. The role of additives when ensiling red clover-grass mixture for biogas production. Grassland Science in Europe 18: 563-565.

Seppälä, A., Heikkilä, T., Mäki, M. \& Rinne, M. 2016. Effects of additives on the fermentation and aerobic stability of grass silages and total mixed rations. Grass and Forage Science 71: 458-471.

Winters, A.L., Fychan, R. \& Jones, R. 2001. Effect of formic acid and a bacterial inoculant on the amino acid composition of grass silage and on animal performance. Grass and Forage Science 56: 181-192. 